International Journal of English Literature and Social Sciences
Vol-6, Issue-2; Mar-Apr, 2021
Journal Home Page Available: https://ijels.com/
Journal DOI: $10.22161 /$ ijels

\title{
Nigerian Drama and Ideological Commitment: A Study of Selected Plays of Femi Osofisan and Olu Obafemi
}

\author{
Florence. A. Elegba
}

Department of Languages and Liberal Studies, School of General and Administrative Studies, The Federal Polytechnic, Idah, Kogi State, Nigeria.

Received: 03 Dec 2020; Received in revised form: 16 Feb 2021; Accepted: 01 Mar 2021; Available online: 27 Mar 2021 (C2021 The Author(s). Published by Infogain Publication. This is an open access article under the CC BY license (https://creativecommons.org/licenses/by/4.0/).

\begin{abstract}
Discourse in ideological commitment among Nigerian playwrights has been a controversial issue because critics such as Jeyifo and others accused pioneer Nigerian playwrights of non-commitment to any particular socio-political ideology that can transform the society positively, if compared with playwrights like Femi Osofisan and Olu Obafemi who emerged in the 1980s. The duo belong to the group of Nigerian playwrights that are considered to be socio-politically committed because of their ideological stance. This paper therefore aims at investigating the nature, extent and direction of their ideological commitment in the following selected plays: Femi Osofisan's Red is the Freedom Road and Altine's Wrath and Obafemi's The New Dawn and Love Twirls of Adiitu and Iyunade. Throughdescriptive research method and oral interviews with the playwrights, this study explores the commitment of the playwrights to the conscientisation of the down trodden and to positive social change over time, using Marxism /Brecht's Epic theories as its theoretical frameworks. The study finds the selected plays as relevant in revealing the playwrights consistent commitment to the revolution of the mind of the poor majority through conscientisation, mobilization and collective effort to fight bad governance and the oppression of the poor. The study concludes that the playwrights are fully committed to positive social transformation of Nigeria and recommends among others, that their plays should be read and acted in schools and public places for the purpose of conscientising the Nigerian populace. They should also actively participate in Nigerian politics to realize the kind of Nigerian society they crave for in their plays.
\end{abstract}

Keywords - Nigerian Drama, Ideological Commitment, Conscientisation Good Governance, and Collective Effort.

\section{INTRODUCTION}

Discourse in ideological commitment among playwrights before the 'emergent' playwrights in the mid 1970s and 1980 s in Nigeria, was a controversial issue. This is because critics like Jeyifo, Obiechina, Gbilekaa and others accused the earlier Nigerian playwrights- J.P. Clark, Wole Soyinka and others of non-commitment to any particular socio-political ideology that can positively transform the society. These earlier playwrights were presumed to only reflect vicious circles of societal woes that are considered irredeemable (Gbileka, 1997, p. iii). This perception appears incorrect because there is no writer who is not committed to one cause or the other given that no writer writes in vacuum but rather through inspiration drawn from certain medium and in pursuance of a cause. It would appear that the seemly no clear-cut ideology of the earlier playwrights and the overtly declared and proclaimed ideology of the 'emergent' playwrights earn them the parlance non-committed and ideologically committed playwrights respectively.

Despite the controversy over commitment or lack of commitment among literary artists in Nigeria, a careful study of the development of Nigeria drama over time, shows its metamorphosis from oral literature to the current post-modern Nigerian literature which majorly has been responses to colonial, post-colonial and neo-colonial experiences and the socio-economic and political aftermaths. This is because Nigeria drama since after 
independence in 1960 has been sustained by reactions to socio-economic and political realities characterised by literary works that are protests against the abuses inherent in the inequalities engendered by the structure of the Nigerian society. As a result of many factors including corruption and exploitation of the masses in the society, Nigerian dramatists especially the class of radical writers, contrary to the earlier playwrights, are committed to rescuing the poor and shaping the society positively towards social change that will improve the quality of life of the citizenry. This category of dramatists demonstrates how politics, ideology and literature are intertwined.

In essence, the perceived shortcomings in the works of earlier playwrights before the 'emergent' playwrights leave much to be desired as the status- quo of social ills, especially bribery and corruption, and exploitation of the poor which keep growing in leaps and bounds. These evil forces typical of neo-colonialism were in ascendance in Nigeria despite the ubiquitous satirisation of same in literary works. This loathsome situation among other things inspired the committed writings of the literary artists in the early eighties. These are the people with a type of theatre which Obafemi and Yerima referred to as "dialectical theatrical tradition" (Obafemi \& Yerima, 2004, p. 5) and also described as "theatre of ideology and politics because of its commitment to social and historical reconstruction through class struggle and a proletarian consciousness" (Adelugba \& Obafemi, 2004, p. 153). It was a shift in paradigm and thematic preoccupation.

The committed Nigerian literary artists therefore use literature as a revolutionary weapon for political liberation-for fighting against all forms of subjugation and the challenges of contradictions in the society. They commit their arts to national struggle and to true and total freedom that can engender progress and development. That is, gaining true independence from the colonial overlords; as well as resisting the forces of internal imperialism. Thus, these Nigerian literary artists are considered socially and politically committed to the good of their society by seeking a form of change that can usher in a new social order of liberty, justice, human dignity and improved quality of life for all.

The committed playwrights demonstrate their ardent devotion to effecting social change aimed at improving the citizens' quality of life by creating awareness, educating, informing, and entertaining the populace. This is because drama is a representation of human life on stage. It is one of the literary genres which writers usually explore as a tool to mirror the realities of man's relationship with his fellow man in the society. Drama can be used effectively to conscientise the populace towards positive social change. This is done by projecting the happenings in the society with the primary intention of exposing social vices such as corruption, oppression, dehumanisation; and advocating the sustenance of societal virtues like justice, equity, peaceful co-existence, progress, honesty, and dignity of labour among others, as playwrights create consciousness in the audience to take appropriate step towards freedom from oppression of the poor majority by the few but rich members of the society.

The pre-occupations of these playwrights shifted from satirising the unfortunate practices of the political leaders and their cronies, towards the conscientisation of the masses to the happenings around them; and also by extension rousing the impoverished and deprived to take appropriate collective action(s) to effectively confront and subdue the manifestations of corruption, injustice, nepotism, embezzlement, bigotry, opportunism and oppression among other social ills in Nigerian society. This is done as succinctly expressed by $\operatorname{Ogu}(1986$, p.119) when he asserts "by awakening the sensibilities of the down-trodden to their plights as oppressed, dehumanised and subjugated people who need revolutionary activities to liberate themselves".

Notable writers and works of that era of giving hope of freedom and better life to the poor, include Kole Omotoso's The Curse (1975) and Shadows in Horizon (1977); Bode Sowande's The Night Before (1979) and Farewell to Babylon (1979), Femi Osofisan's Once upon Four Robbers (1980); No More the Wasted Breed (1983), Morountodun (1983), and Red is the Freedom Road (1983). Others are Olu Obafemi's Night of a Mystical Beast (1986); The New Dawn (1986), Naira Has No Gender (1993), Scape Goat and Sacred Cow, (2002), Suicide Syndrome et cetera. It needs to be mentioned in passing that the decade following the end of the Nigerian civil war in 1970 was a period with a large inflow of petrol-dollar to the nation's treasury and an outflow of funds by way of public spending; siphoning and squandering which inadvertently became the fountain head of hydra-headed corruption, nepotism and other social malaise. The thematic preoccupations of some of the listed works and others like them are therefore pointed response to the poignant decadence in the society.

The emergent playwrights constituted the set of committed writers who espoused their socialist belief and vision in their plays aimed at creating an alternative better society. Their efforts are geared towards realising an equitable society by overthrowing the class of oppressors through collective action. They articulate their convictions, commitment and aesthetic ideals through appropriate themes, narrations, characters, settings, situations, events 
and language etcetera. Though, their efforts have not accomplished a classless society they envisioned, but they are pushing at drawing the attention of the poor majority to the need to reject oppression through collective action. In the opinion of Awodiya (1988, p. 224)

These writers are committed to liberating the common man from the shackles of the corrupt oppressors as reflected in their proletarian philosophy about the society. Through their plays and social visions, they awaken the revolutionary consciousness of the down-trodden to the need to resist oppression through collective efforts.

This study therefore, investigates the works of two selected 'emergent' and ideologically committed Nigerian playwrights- Femi Osofisan and Olu Obafemi. The study strives to explore the nature, direction, and extent of their ideological commitment and how the dramatists combine their artistic craftsmanship with their revolutionary aesthetics in their plays without recourse to violence, to express their great concern for the poor majority.

\section{LITERATURE REVIEW}

Ideological commitment refers to a devotion to certain philosophy or idea on matters that may be socio-cultural, economic, political and religious or any other areas of human endeavour. The said devotion or commitment can be by an individual, group or even a nation. Attempts are often made by the devotees or ideologists to project such ideas, values, beliefs, convictions or principles as ideal which everybody should subscribe to or imbibe. Strategies for the spread of such commitment may range from the sublime to the ridiculous; and from being voluntary to the outright use of force or a combination of methods to perpetuate or proselyte it to gain followership. In fact, some African committed literary artists may be fanatical about idealism to the utter neglect of realism in the process of showing their commitment.

Rabkin (1972, p. 164) admits that the term commitment "includes both the conscious involvement of the artist in the social and political issues of his age (in contrast to deliberate detachment or political non-involvement) and specific political obligations which the artists assume in consequence of this involvement..." Rabkin's description of commitment reveals the importance of conscious involvement on the part of the artist and the political obligation that comes with involvement. The obligation on a committed artist is more than just political but also socioeconomic, religious and cultural.

Amadi (1983, p. 35-40) posits that "the committed writer is one who consciously uses his writing as an instrument for furthering the cause he believes in". He asserts that a committed writer does not make general statement but he is out to change a particular situation, or to initiate, reverse, or modify a mode of thinking. His preoccupation according to him "is intense and his subject looms so large in his field of view that he sees little else and his literature of commitment depends on the matter of the moment that is, the socio-political situation it portrays, for its success". The recurring issue in a committed writing include conscious involvement in socio-political matters with the aim of positive social change. Cuddon (2013, p. 139) is also of the opinion that "a committed or engaged writer is one who through his work, is dedicated to the advocacy of certain beliefs and programmes especially those which are political or ideological and in aid of social reform".

The post-independence socio-economic and political realities in the various African countries with its struggles against colonialism, post colonialism, and neocolonialism left much to be desired. As a result, the situation offers some ready- made themes to the African literary artists who, not only expose the social vices, but offer suggestions for a better society through their creative endeavours. The situation cannot but leads to the artist's conscious involvement in writing about socio-political themes in society aimed at positive social transformation. Major among such themes are corruption and bad governance which cut across the various African countries and the African literary artists have arisen to the challenges of the social contradictions in the society.

Among the ideologically committed literary artists who use their works to expose the socio-economic and political realities of post-independent Nigeria and thereby seeking a form of change that can usher in a new era of social order of justice, liberty and human dignity in all ramifications are the playwrights selected for this study. Thus, a discourse of their socio-political commitment inadvertently highlights the inextricability of literature and politics.

Jeyifo (1985, pp. 46-54) writing on the nature of commitment in African drama observes that "engagement and radicalism in African drama arise, not out of a vacuum, but in a context that is historically and culturally heterogeneous and comprehensive". He identifies different levels of commitment in the engagement of different playwrights and their plays and he enumerated the following factors as indicators of the real nature of African dramatists' commitment: "what social class they predominantly or obsessively deal with, with what sympathy, antipathy, or ambiguity, and with what distance or solidarity" (p. 47). Jeyifo uses the word engagement to describe plays that pertain to a dominant pattern dealing with social and political realities. Some of such plays and 
the playwrights include; Wole Soyinka- Kongi's Harvest, Madmen and Specialists (Nigeria), Ama Ata Aidoo-The Dilemma of a Ghost (Ghana), Ebrahim HusseinKinjeketile (Tanzania), Ngugi wa Thiongo -The Black Hermit, The Trial of Dedan Kimathi (Kenya) and Athol Fugard-Sizwe Bansi is Dead (South Africa). Jeyifo maintains, that the playwright's attitude is informed by revolutionary combativeness and optimism. He admits that "the final level of categorisation may be found in the kind of cultural critique implied in a playwright's dramatic universe" because according to him, "committed drama contests and endorses not only a political or social reality, but also its cultural ambience".

Elucidating on a writer's commitment in using literature for social change,

(Achebe, 1988, p. 117) declares:

When we speak of a writer's commitment we mean his attachment to particular social aims and the use of his writing to advance those social aims. This; of course, implies a belief that literature can and should be used as a force for social change, and a writer has a responsibility to do so.

Obiechina (1988, p. 4) also highlights what should be the attitude of a writer to the plights of the poor and the oppressed when he posits that Nigerian writers:

Should have a special allegiance to the down-trodden and the socially handicapped, to the women, the children, the unemployed, the sick; all those who are not able to fight their own battles. The writer should put on his armour and charge into battle in defence of the defenceless. It is my view that the writer in Nigeria today has to take his position against the oppression of the people, all forms of brutalities and of unwarranted violence against the masses.

This study therefore examines how the playwrights use their dramaturgy to champion the cause

of the down-trodden as they fused Marxian / Brechtian and African traditional aesthetics to

conscientisethe poor in their quest for positive social change.

\section{METHODOLOGY}

This study adopts the descriptive research method and the instrument of oral interview. These were used to analyse the four selected plays- two fromFemi Osofisan and two from Olu Obafemi respectively. The plays served as the primary data in order to interrogate their ideological commitment, social, political and artistic visions as explored in the plays. The purposefully selected plays are
Femi Osofisan's Red is the Freedom Road (1983) and Altine's Wrath (1986) and Olu Obafemi's The New Dawn (1986) and Love Twirls of Adiitu and Iyunade (2016).

The secondary sources of data collection include reported interviews with the playwrights by previous researchers in textbooks, journals, published essays/articles, relevant previous academic research works such as dissertations and theses, papers presented at seminars, conferences, public lectures and mass media sources such as Magazines, Newspapers and the internet.The study is interpretive and the texts are purposefully selected just as the playwrights are chosen because of their rich sociocultural backgrounds in addition to their profound knowledge of the country's socio-economic and political history. Marxist literary approach/Brechtian Epic theatre theory provides the analytical tools for the reading and analysis of the selected texts.

\section{Theoretical Framework}

\section{Marxian / Brecht's Epic Theatre Theories}

This study adopts Marxism / Brecht Epic Theatre theories as the theoretical frameworks. This is because of their relevance in analysing man's material existence and class struggle. They equally consider the role of literature in society as an instrument of socio-economic and political change, they show great concern for the general well-being of the masses and also see literature from ideological perspective. While Marxism emphasises more on the socio-economic class relations between the poor majority and the few rich oppressors and the revolutionary strategy of breaking the yoke of oppression, Brecht infuses Marxism into his epic theory but takes special interest in stagecraft which Marxism does not. This therefore accounts for the choice. The two theories and their features shall be briefly discussed.

Classical Marxism theory was derived from the works of two German philosophers; Karl Marx (18181883) and Friedrich Engel (1820-1895) who became friends by reason of their common perspectives on philosophy in general and capitalism in particular. Their collaboration led to the publications on capitalism (The Communist Manifesto and Das Kapital for example). Marxism emphasises the idea that social life is founded upon 'conflicts of interest' most particularly between the Bourgeoisie and the Proletariat. According to Duiker and Spielvogel (2008, p. 428) "Marx believed that Economic Determinism, Dialectical Materialism and Class Struggle were the three principles that explained his theories". He rejected the tenets of Romanticism in favour of dialectical materialism. He was stern in criticising the injustice inherent in the European class/capitalist system of economics operating in the $19^{\text {th }}$ Century. 
Some of the main features of Marxism uphold that:

i. a society is made up of social classes based on relationship to the means of production.

ii. existing society's mode/means of production is the economic base (infrastructure), while the political and ideological sphere of influence constitute superstructures of the society;

iii. the history of all existing (capitalist) society is the history of class struggle to protect class interest;

iv. the proletariat and the bourgeois constitute the material foundation of any society with an unending struggle (conflict and tension) between them to bring about change in the mode of production, and ownership of the means of distribution which is the most important variable to determine each distinct period (or epoch) in history;

v. all ideological systems are the products of real social and economic existence (dialectical materialism) and they are neither ideal nor the products of providence (divine or spiritual) and should therefore be questioned. In essence, social inequality is man-made and can be changed by man. In this wise, religion is considered 'the opium of the people';

vi. class society where the means of production is concentrated in the hands of a few is anti-progress;

vii. the ruling class are economically powerful and consolidates its hegemony over other classes through the (mixed) use of force (e.g. the police and army) or ideology/socialization (e.g. the mass media, social workers and teachers). These are called 'Repressive State Apparatuses' (RSA's) and 'Ideological State Apparatuses' (ISA's) respectively; the oppressed should struggle to free themselves from exploitation and oppression through collective efforts by way of revolution in order to establish a dictatorship of proletariat'. The revolution is inspired by conscientisation (class consciousness/awareness) under the guidance of the intellectual; and

viii. Literature as a product of society and history should be used to liberate the masses.

\section{Brecht's Epic Theatre Theory}

Bertolt Brecht (1898-1956) was a German radical playwright and director who revolutionised theatre through his Marxist ideology which Adeoye (2009, p. iv) describes as been "contextually nurtured by psychology and sociology in theatrical presentations". Through his experimental theatre, Brecht recreates history to challenge man towards critical thinking and social change. Some of the plays of this celebrated playwright with great influence on the modern theatre include: Galileo, The Measures Taken, Mother Courage, The Good Woman of Setzuan,
The Caucasian Chalk Circle, Seven Deadly Sins of the lower Middle Class, Three Penny Opera, Saint Joan of the Stockyards and so on.

Brecht's epic theatre is therefore, a form of theatre associated with the German theatre movement in the 1920s. It is a didactic drama that is presented in a series of loosely connected episodes that are not chronologically arranged and each episode can stand alone to communicate without recourse to the preceding episode. Brecht's plays tell stories that articulate political attitudes and gestures through body language and facial expression. It perceives clear socio-political messages as more important than characters. Edde (1991, p. 185) sees epic theatre as essentially dynamic with the task of showing the world how it changes and how it may be altered when he asserts:

Brecht's epic theatre according to him does not only turn the audience into an observer but also agitates its capacity for action. In the epic theatre, among other aspects, "the human being is the object of inquiry" he is both "alterable and can be altered".

Ewen (1969) quoted by Edde, (1991, p. 189) asserts that "Brecht's epic theatre is a fusion of the Marxist dialect and the traditional or formalistic elements". Edde further argues that Brecht through his epic theatre attempts to "combine the rational, and the irrational, the simple and the complex... among others to alienate and de-alienate, very dialectically and rationally, twentieth-century man and his de-humanizing and anonymous forces" with the aim of making his protagonists and the audience to view the world in new perspectives. This idea is what Ewen (1969, p. 34) emphasises when he opines that:

The essence of the new theatre is to dealienate man, restore him to a consciousness of his active power and to retrieve from him his prize possession, his creative potential, as well as his product-to provoke him into seeing that change is possible.

Baranger (1995, p. 128) also describes Brecht's plays "as a series of loosely knit scenes, each complete in itself... His epic play is therefore, historical, narrative, episodic and highly theatrical. It treats humans as social beings in their economic and political milieus". Baranger claims that non-literary elements of production such as music, acting style, lightning and moving scenery retained their separate identities in Brecht's epic play.

Brockett and Ball (2004, pp. 188-190) opine that Brecht intends to make the audience evaluate the socioeconomic implications of what they watch in the theatre and see the need to alter the economic system and work to bring about changes. Abubakar, (2006, p. 28) sees "the epic theatre as a place of instruction and entertainment and 
the actor as the instructor and entertainer". He admits that "Brecht focuses on the audience and not the actor; its activity and not its inaction; its comprehensive ability and not the actor's know how". This is because of Brecht's concern for the audience and the impact on him as the receiver of the message who reflects on the facts and actions of the play without empathy.

Brecht through the alienation-effect demystifies the stage, the actions and the actors to encourage audience participation through interruption of performance to make the actors respond to the audience. He equally demystifies the stage through the techniques of play-within-play, the use of narration, actor's detachment from his role, audience participation, elements of songs, music, dance and other devices, in order to enable the audience to respond critically to what he watches on stage. Nwabueze (2011, p. 59) also describes epic theatre as "essentially panoramic and intended to teach political and moral lessons, as well as create the necessary instrument for social change".

Douglas (1997, p. 4) on Brecht's Marxist aesthetics asserts that Brecht derives his political aesthetics from Marxian ideas and this has helped to shape the form of his theatre theory and practice. Douglas identifies alienation as the primary theatrical device of epic theatre. He concludes on the note that "Brecht found Marxism a productive source of ideas both to understand the world and to revolutionize art. Thus, ironically the Marxian revolution has more fruitful results in theory and cultural practice than in actual politics" (Douglas, 1997, p. 4).Dicggan (1999, p. 3) asserts that Brecht's involvement with Marxism is well documented and for him, "there were three essential points of contact between it and epic theatre - Materialist conception of man, the primacy of reason, and an unshakeable belief in the possibility of changing the world". Brecht's epic theatre from the various descriptions is therefore a theatre that, in line with Marxism sees the economic structure in society as the cause of class stratification and the need to appeal to the audience' sense of reasoning, so that through critical thinking they would be jolted into consciousness for possible positive change. Brecht combines Marxist dialect with traditional elements to propagate his clear socio-political message as he picks what he considers relevant to his pedagogical theatre.

\section{Features of Brecht's Epic Theatre}

Brecht's epic theatre has the following features among others:

- disregards the Aristotelian model of unity of action, time and place since the narration can span many different locations and time frames;

- the episodes are loosely connected;
- the message is socio-political in nature and is clearly presented in a narrative form;

- it refers to audience as spectators and they are free to give personal interpretation to plays and draw conclusions of how the events are stringed together. The audience is also expected to be critically aware by responding through critical thinking because epic play appeals to reason and not emotion and therefore provokes debate and educates the audience, since it seeks for change;

- it employs Alienation-effect technique to detach the audience and actors from a play and its performance and to make them to be objective and not to empathize or identify with the characters or the events in the play. To achieve the alienation effect, "Brecht changes scenery before the audience, makes use of projections, hoists, treadmills, and musicians on the stage; It also employs parables to emotionally detach the audience from the realityof the play". Source: Powered by Weebly Retrieved from (http://msbdramqueen.weebly.com/epictheatre.html);

- it makes use of common figures as narrators and stereotyped characters with generic names such as peasants, workers etcetera;

- it also makes use of history to situate the actions of the play in the past in order to draw parallel with contemporary events. The purpose of this is to help the audience to view the events of the play with emotional detachment and respond by thinking critically;

- it employs music to comment on the actions of the play and also for alienation effect that is, to neutralise the emotion of the audience; and

- tragic hero in Brecht's Theatre is not an individual hero or heroine but the tragedy of the proletariat because he sees it as "the tragedy of humanity as a whole" "that is caused by man and is unnecessary" (Edde, 1991, p. 53, 187).

\section{RESULTS AND DISCUSSION}

\section{Textual Analysis of the Selected Plays}

\section{Economic Structure, Class Conflict and Struggle for Freedom in Osofisan'sRed is the Freedom Road and Altine's Wrath}

Osofisan depicts economic structure; class stratification and class conflict in the selected playsin this study to expose the evil of capitalism which puts the masses at the mercy of the few rich oppressors who own and control the means of production and distribution and to show his commitment to the liberation of the down-trodden. For instance in Red is the Freedom Road he presents the oppressive King and his Chiefs and Akanji and his co- 
Slaves in this short play with six major characters. In line with epic theatre, the play is episodic in nature. It is set at the bank of a river side between the palace and the shrine.

The conflict in the play is between a feudal system of government that is exploitative and draconian and the captured slaves. Osofisan depicts slavery as a human condition that puts people who are born free in their own community in servitude or captivity forcefully to a master in a foreign land. The slaves are deprived of their privacy and personal freedom and they work without pay for their master without any term or tenure of their servitude. The economic structure in this play put the King and his chiefs as masters and task masters who dehumanise the poor slaves and deprive them of their freedom through oppression.

Ibidun relates the oppressive attitudes of the slave masters to Akanji in the expression below:

Ibidun: Our masters have become more cruel with us. Each day their whips cutdeeper into our skins. They harness our women to their chariots; feed our children to their gods. The men have waited long enough for you. Now the suffering multiplies. They're beginning to lose hope. You have done nothing for them (p. 117).

The above statement reveals the degree of man's inhumanity to man in a capitalist society where the rich and the powerful lord it over the poor majority and wish that the poor remain in his poor state perpetually to serve him- the rich oppressors.

Osofisan in line with the Marxian / epic theatre tradition in this play, also stresses the revolutionary importance of collectivism that is, proletarian struggle against oppression and dehumanization as can be seen in Akanji's encouragement to the warriors on the need for collective action:

Akanji: Warriors, the road is hard but straight. We shall fight our way to freedom. Why, together we are three hundred men. Most of the native troops are out, occupying foreign lands. Some still remain, but together we can match them man to man. There are three hundred spears in our hands, but each of us is more than two men. Will you fight with me? (p. 131).

\section{Soldiers: $\quad$ Lead on. Freedom, or death!}

Soldiers: $\quad$ You delay! Lead us, Basorun!

A Soldier: Death to all oppressors.

Soldiers: Death to all oppressors.

Akanji: Take your arms. Shake the cobwebs from your muscles! O all

men, follow me! (p. 132).
At the strike of martial songs, through their collective efforts they overthrow the tyrannical king and force him to submission. Akanji declares freedom for all:

Akanji: Tonight is the night of freedom! Freedom, my brothers!... All slaves will be free. There will be none among us in chains! All captured shall return to their homes. There will be no detention. I Basorun, now King, I am speaking with my mouth. Ours is a mission of peace. Let the torches speak for me (p. 135).

Osofisan draws attention to the power of collective will of men who are particularly motivated and co-ordinated for freedom in this revolutionary play to show that man's destiny to a great extent is in man's co-ordinated action against anything that limits him from achieving socioeconomic and political freedom. He seems to also suggest that the oppressor will surrender when the oppressed struggles for his freedom.

Through Akanji, Osofisan's dialectical materialist philosophy awakens the consciousness in the slaves. They perceive the objective way of achieving their freedom as Akanji asks them the question "will you fight with me?" Osofisan in this demonstrates his ideological commitment to the freedom of the masses from all oppressive and dehumanizing conditions in the society. Though Akanji died at the end but he succeeds in gaining freedom for the slaves as he declares:

Mother I have come, I too, your cursed son.

I have come to yield my life...I have come as you ordered.

I have set our men free.

...They are rulers now... our men are no longer slaves,

I have placed their bottoms on a throne.

Your death was not in vain (p. 137).

Red is the Freedom Road may be addressing the Nigerian Civil war, but it seems to be a prophecy about the current global violence as a result of inequality orchestrated by economic structure, which in turn leads to class stratification and the struggle for freedom from the oppressive socio-economic and political systems by the oppressed majority. Osofisan desires a social change in which both the oppressor and the oppressed will work out a modality of sharing the commonwealth equitably without recourse to war. In this play, he wishes that, humanity will learn from the various world wars and civil wars in different nations of the world and seek for alternative means of resolving conflicts than war. He suggests an amicable way such as dialogue.

In Altine's Wrath, Osofisan also depicts how the economic structure leads to class stratification as Lawal the Permanent Secretary and his cronies represent the rich 
oppressors, while the poor farmers whose lands were taken by Government without compensation and Altine- Lawal's wife represent the oppressed. To portray his socioeconomic status, Lawal's sitting room where he sits at the opening of the play is described as well-furnished and Lawal as Government representative acquires poor farmers' land without compensation over several years and when confronted by an old classmate Dr. Mrs. Aina Jibo, Lawal insults and despises her for daring to bring the peasant farmers to his house. Lawal oppresses his wife and the peasant farmers because of his political power and economic status as elite.

In line with the Brechtian philosophy of the concern for the downtrodden, Osofisan reveals how the rich oppresses the poor in Altine's Wrath. He employs concrete images in Altine's Wrath to portray the relationship between the rich and the poor, the oppressors and the oppressed. The images are meant to communicate clearly the reality of oppression in the society in order to awaken the audience's consciousness. Osofisan uses the metaphor of monkey, goat and banana in this play to represent the rich and the poor. Lawal, the Permanent Secretary represents the rich and the elite who oppress the poor and even their wives. Altine his wife, Onene and Audu the peasant farmers whose landed properties were taken by government without compensation are the poor and the oppressed in society.

Osofisan reveals the attitude of the rich oppressors to the poor and people they considered as of no consequence, when Lawal insults and despises Dr. Mrs Aina Jibo his old class mate for dare to bring the peasant farmers whose farm land was taken over by government without compensation to his house. He sternly warns her never to repeat such or face the consequences. He chased her and the peasant farmers out of his house. Through the dialogue between Lawal and Aina, Osofisan reveals the rich's arrogance and contempt for the poor and women as exemplified by Lawal's attitude in this conversation:

Lawal: What! You wretches! You dare say such things in my house! ... Aina take these men before I get them locked up!

Aina: Forget that, Lawal. Just think of their sufferings. Think of the injustice of it all.

Lawal: Which injustice? We shouldn't plan the town any more because of wretches like these. (In a rage) Rotten! ... You are in a wrong country, let me tell you! You and your type, you have no place here! And in case you've forgotten, I'll remind you! Women here don't dare raise their voice when men are speaking! And you'd better get that back to your head!
Lawal boast of his possession of companies, land, houses, car, horses, and how he employs hundreds and how women who are better than Aina kill themselves to get to his bed. In anger, he chased her out of his house when he says "I give you two minutes to clear out of my house!" (He strides out) (pp. 17-19).

Osofisan equally depicts Altine's Wrath as a play full of domestic matrimonial problem which shows Lawal's level of infidelity and exhibition of domestic violence through his obsessive beating and battering of his wife. The play explores women's experiences on issues of exploitation, self-identity, subjugation and domestic violence. It shows how the structure of Nigeria's patriarchy society helps to militate against women's expression of self. In the play, Altine is seen as secondclass citizen. She is a wife, a mother, and a woman who lost her voice from the beginning of the play therefore, should not be seen or heard, but rather should be oppressed, abused, dehumanised and battered through domestic violence.

Osofisan further reveals Lawal as a brute who cares less about the physical, emotional and psychological feelings of his wife when he reacts brutally to her interruption of his narration to Mariam his mistress by accidentally breaking a plate. (He is enraged) What! What's that? You stupid, blundering imbecile! You broke that expensive plate! Why are you always so clumsy, eh? I'll teach you a lesson today! (Move to impress Mariam, he takes out a belt and whips her... he hits her again...) Get out of my sight! Tafi mana!

Osofisan's reflection of male chauvinism in the play exposes readers to certain tendencies against women in society and the playwright's concern for the female gender in the society even though in a personal interview with this researcher on issue of feminism, Osofisan asserts:

'Feminist' is again just another label. All I know is that I am greatly concerned about the plight of women in our society. They are usually treated as inferior beings, made to carry heavier responsibilities with less compensation. Some of the fault of course lies with they themselves; some women are the agents of this female oppression, especially with regards to some practices in the traditional society. So I write about this, exposing both the wrongs against them as well as showing their positive potentials. However, I do not lionize women just because they are women. I have no such gender bias. There are women who are evil, and there are those that who are splendidly heroic. Just like men, they are all human beings. That is why I believe that some of these feminist advocacy is wrongheaded at times, and purely chimeric.(Excerpt from theInterview granted the Researcher 27/7/2017). 
Ojediran (2016, p. 175) considers Osofisan's diction in this play as his "intention of exposing social injustice against women and the need for women to seek redress by crying out rather than keeping quiet". She admits that Osofisan uses the metaphor of silence and audibility in the play "to explore women's ability to either speak out against or condone the unpleasantness of the unjust sociocultural, marital, economic and political issues associated with patriarchal society that does not allow women to act on their own volition" (p.175). Osofisan clearly demonstrates his ideological commitment to expose the limiting forces against women from achieving their potential in the society. In line with the Marxist/ Brechtian ideologies, he conscientises the oppressed and strongly advocates a positive social change in Altine's Wrath.

\section{Class Stratification, Class Conflict and Struggle for Social Change in Obafemi's The New Dawn and Love Twirls of Adiitu and Iyunade}

In line with the Marxist/ Brechtian aesthetics, Obafemi in The New Dawn,also depicts class stratification as he presents the tyrannical Emperor and his wicked soldiers as the class of the oppressor while the poor and brutalised children, the youths, the farmers, teachers and civil servants as the oppressed for purpose of satirising the oppressors and conscientising the oppressed to take appropriate action for his freedom. Obafemi presents the arrogant Emperor who sees himself as second to God and who is divinely empowered to 'jail, bury alive if the process of organised killing wastes good time, to drink blood if water has no taste" (p. 30). The Emperor demonstrates his cruelty and pride further by warning sternly, the radical youths- the leaders of tomorrow to behave themselves and not to play with death by grapping the cobra by its expensive tail, or holding the elephant by its costly tusk, by not putting their fingers inside the ajarred jaw of a famished lion, because "a bent double old hag who trifles with a cobra is writing his obituary" (p. 28).

The Emperor does not believe in equality because he considers himself privileged. He believes that the society is fragmented into unequal segments when he declares "I say some are created to fetch water, others to drink the water. Some are born to suffer, to cook so that we can eat the choicest and most proteinous of meat" (p. 29). To this tyrant and dictator, alleviating the suffering of the poor is not a concern because to him, they are created to be poor and to suffer, therefore, to him the cry for a social change does not make any meaning. The economic structure which concentrate means of production, distribution and endowed the few privileged with the superstructure of state apparatus played out in this drama.
The Emperor using all the state resources at his disposal to oppress the populace and to stratify the society into the class of the oppressors and the oppressed is a case in point.

The outrageous killing by the government and its agents demonstrates the reckless and wanton destruction of innocent lives by the dictators who have no respect for the sanctity of human lives. The collective struggle against such by the oppressed set the conflict of the play. Such killings can be likened to extra-judicial killings and assassinations common in military and civilian regimes of Nigerian society. Aina's emotional outburst on the manner in which the lives of the helpless children are lost calls for revolutionary proposition. She laments the inhuman killing of the children in the land as seen in her dialogue with Egbon Alade, the conservative in the play:

Alade: Proposition please. Do we organize a light raid for commanding officer, second in command...to teach them a lesson?

Aina: What lesson? ... (Rises). The lives of the helpless children are lost. Well you men don't feel the pain of child bearing, (slow baby-prating rhythm accompany the narrative). For two years between conception and weaning, the only moments of relief come during orgasmic climaxes...otherwise from the moment when the monthly pains cease, through the nine months of carriage, it is untold sorrow... No Egbon Alade (major movement) it must be blood for blood. For power marionettes must go... so that our pains will no longer be in vain (shows emotions by shedding tears (pp. 14-15).

Obafemi through Aina in the above expression has drawn the battle line between the oppressors and the oppressed as the class conflict ensues and the oppressed desires freedom. This can be seen in Aina's unequivocally calls for social justice and the removal of the Emperor.

Obafemi in The New Dawn uses the group of intellectuals (Tayo, Dele, Aina and Funke) to reflect the class struggles, the minds and attitudes of the group about the neo-colonialist of the period. Alade sees them as toothless bulldogs and all their revolutionary muscle flexing as fake, when he describes them as 'lazy wrestlers who flex their muscles to the wind when their enemies are not in sight, but flee at the sight of the opponents (p. 22).Alade queries the sincerity of purpose and the commitment of the elite to the quest for justice and social change. This is as a result of their failures in projecting meaningful and collective conscious struggle for the liberation of the masses in the society. In their dialogue, Alade says, "I go now, why you fail to find the way into the liberation' (p. 24). Commenting on their vain struggles he maintains 'all you do is chatter, out there, there is the real touch with the cord of our being" (p. 24). 
The elite seem to pursue shadow rather than reality in their quest for liberation and social justice. They are more concerned with their personal interests. Ikerionwu (2014) asserts that "unarguably, the bane of the radical elite is their half-hearted commitment to the struggle for liberation since their admission into the capitalist fold. They too are overtly or covertly involved in the exploitation, selfaggrandizement, greed and ostentatious life" (p. 107). Tayo testifies to this when he admits:

...we are part of the rottenness, the grap and greed. This hounding of the powerless. Look at your shirt and mine and cast your mind back to those beggars in the gutter. You step into your air conditioned, tinted glass Volvo car, you can't hear the painful cry of the starved whose three meals a day have been stolen to buy your car (pp. 15-16).

Odekunle-Awoyale (2000, p. 210) sees Obafemi's The New Dawn "as a powerful play that condemns and revolts against the dehumanisation of the masses by the ruling class, characterised by indiscriminate killing of innocent children and the class struggle by the so-called elite". She maintains that the play calls on society "to get rid of the dusk of death and embrace the 'the birth of a New Dawn". Abubakar (2005, p. 34) also condemns the greed and grap attitudes of the 'radical' elite when he hints that "apart from slogans, the group is preoccupied more with the pursuit of his own 'rights' and not the rights of the millions that toil to pay taxes from which it is paid for merely moving files". For instance, Dele is concerned about the delay in his promotion and his car loan than coming early for the meeting. Obafemi satirises the elite for lacking the revolutionary zeal needed for social change.

The radical youths ignore the Emperor's threats and remain undeterred. They mobilize, educate, and conscientize others in the community for the revolutionary quest for a better society. There are also the peasant farmers who are committed to the struggle for a better society. The youths play active roles in ensuring that collectively the various groups can impact the society positively.

Obafemi in The New Dawn therefore presents these various interest groups in their different generations and radical capacities. He exposes the contradictions within each group's attempts that frustrated their efforts at achieving the desired revolution. Obafemi uses the play as his creative vision in line with his Marxist/ Brechtian ideological foca to project his quest for social justice. He uses the play to create awareness among the people as well as an ideological base to gear them towards collective consciousness of the cause of their sufferings to be the ruling elite and their agents and the need to collectively uproot them through mass struggle.

In The New Dawn, Obafemi tries to make it clear that to achieve the desired socio-economic and political change, it usually takes time to conscientize, educate and mobilize the people for collective action. Such effort is usually characterized by accusation, counter-accusation, confrontation and different manners of blame games as seen in the play when the youths accuse the elite of inconsistency in their thinking without action and the elite also accuses them of youthful exuberance.

In Love Twirls of Adiitu and Iyunade, Obafemi presents Adiitu's determination to struggle against the forces of poverty, change the status quo and join the group of the wealthy.The playis Obafemi's experimentation of adapting D. O Fagunwa's classical novel Adiitu Olodumare as a play on stage after he successfully translated it to English with the title Mysteries of God. In line with the epic tradition, the play consists of seventeen short episodes creatively woven together to reveal Adiitu's transformation from a young son of poverty stricken parents-Obiri-Aye and Iponjudiran to a rich and influential young man who falls in love with and marries a beautiful princess of Ajedubule village. The play portrays Adiitu's stages of growth from childhood through adulthood into manhood as a representative of any young man in society characterised by ups and downs and also meetings with different kind of beings human and subhuman personages with different and many sided tendencies such as "the good, the bad and the ugly" (Blurb).

Adiitu becomes fed up with his inherited poverty from his parents, leaves Ilakose his village in search of fortune that will turn his life around for good. The economic situation of Adiitu's parents-Obiri-Aye and Iponjudiran reflects their poor condition and they represent the down-trodden in society, while Ademeto and Iyunade- the prince and princess of Ajedubule, King Ofintoto, King Adefela and the Chiefs represent the class of the rich and influential in their communities. Adiitu struggles to become wealthy and join the class of the influential through determination and hard work.

\section{Youth Empowerment and Self-Reliance in Love Twirls of Adiitu and Iyunade}

Unjust socio-economic and political structures breed different manners of challenges that an individual confronts in society. Such challenges range from oppression, alienation, economic strangulation such as poverty, hunger, diseases and many more. Obafemi in Love Twirls of Adiitu and Iyunade creatively paints the picture of man's struggle for survival in the face of daunting challenges that are out to cripple and maim him. He emphasises the place of industry, determination, 
resilience, perseverance, persistency and consistency in man's effort at struggling for survival in a capitalist economy like Nigeria with its "survival of the fittest" syndrome.

Love Twirls of Adiitu and Iyunde "captures the aesthetics of the traditional communal existence of man" (blurb). The play reveals Adiitu as a young man who endures hardship, hunger, and poverty as his parents can hardly provide him three square meals. A creditor also invades their home and carts away their clothing materials and other personal effects because his father is a debtor. Obafemi presents Adiitu also as a young man who tolerates insults and embarrassment as he is wrongfully accused of stealing at Agbekoya's farm in Ifehinti village. Adajo-ole's wrongful condemnation of Adiitu for theft, demonstrates miscarriage of justice in human society whereby the innocent is condemned and the guilty is set free.

Obafemi "de-emphasizes poverty and discrimination" which Abubakar (2017, p. 3) admits are "factors disenchanting the youths" in contemporary society, in order to promote industry, self-reliance and economic empowerment. Obafemi portrays Adiitu's persistency and perseverance as he struggles through life before he becomes wealthy, famous and an influential man in Ajedubule community and eventually succeeds in marrying Iyunade the love of his life. Obafemi seems to suggest in this play that man can triumph over various struggles and difficulties he encounters in life, if he perseveres and refuses to lose hope. Adiitu diligently seeks for food in an effort to fight hunger and he finds it, though he suffers insult and embarrassment which make him decides not to return to his village Ilakose, but to proceed "elsewhere in search of a livelihood" (p. 22).

Adiitu's courage, diligence, persistency and vigilance is further demonstrated when he encounters a big, ugly, dirty, and gruesome creature who wrestles with him in an attempt to collect the gourd from him. The trouble spirit struggles in vain as Adiitu removes his mask and exposes the faceless creature. In line with epic tradition, Obafemi demystifies the faceless creature. Surprised at Adiitu's ability to guard the gourd vigilantly, the Mysterious one rewards Adiitu when he comes to demand for his gourd. He declares:

How did you do it? What did you do? Are you sure you are born of a woman? Who are you?! (Adiitu remains mute as the Mysterious one checks him out) Come with me, come! Today I shall give you the stone of wealth! Come, come. Follow me, you shall break the stone and sell it. Any time you need more stones, I shall show you where to dig them up. Come with me Adiitu-Olodumare, my friend (p. 26).
Adiitu becomes empowered. He becomes a rich and successful business man in Ajedubule village thereafter as he sells the precious stone of wealth to people from far and near. He becomes popular and influential with much to eat and to give out, with Onise as his servant who takes care of his house and assists him in selling the precious stones and Esu-Leyin-Ibeji as his friend and business assistant.

Obafemi in Love Twirls of Adiitu and Iyunade explores the theme of love, poverty, hardship, betrayal of trust, arrogance, rejection, deceit and struggle for survival. Most of the themes in the play revolve around Adiitu the hero of the play who though born into poverty rises to fortune. The playwright depicts Adiitu's father's poverty as self-inflicted due to his carefree and prodigious attitude to life. Instead of Obiri-Aye spending his hard-earn income on feeding his family, he wastes his resources in beer-parlours on Arungun and Apa his waster-friends and spends the remaining on Itanje-Eda, his mistress. Obiri-Aye goes into borrowing and becomes a debtor to many creditors.

Adiitu's decision not to return to Ilakose village is borne out of the boredom from the embarrassment of his parents' poverty and the incessant nagging of Obiri-Aye by Iponjudiran, his mother leading to daily quarrel in addition to lack of food. Adiitu takes his destiny into his own hands and chooses to struggle for survival against his father and mother's wish. Adiitu suffers loneliness, hunger, hardship and deprivation in the forest, but endures all and his fortune changes for better at the end as he is empowered and becomes self-reliant.

\section{Findings, Conclusion and Recommendations}

This study finds Osofisan and Obafemi as totally committed socially and politically to the cause of the down-trodden.The playwrights direct their drama of commitment at exposing the social vices perpetrated by the political class and the nature of their commitment is to conscientise that is, revolutionise the mind of the poor (velvet revolution) to the unequal socio-economic and political relations in Nigerian society which leads to class stratification, class conflicts and struggles to maintain status quo by the rich and the struggle for freedom from oppressors and oppression by the poor. The playwrights direct their drama of commitment at exposing the social vices perpetrated by the political class. Their dramaturgies reflect a fusion of both Brechtian and African traditional aesthetics. They claim to have adopted Brechtian aesthetics that are in conformity with their African cultural aesthetics in personal interviews with them.

The plays studied reflect Brecthian aesthetics such as episodic structure with clear socio-political messages. 
The audience is seen as spectators that must put on its thinking cap to critically assess the plays and relate it to contemporary socio-economic and political experiences in his society calling for social change through collective action. The playwrights make use of narrators that are common figures and promotes collective heroism against individual heroism through collective action against unequal power relations in Nigerian society. They employ dialogue, songs, music, and dance as independent elements for alienation-effect purpose and to convey their sociopolitically committed message of positive social change. The playwrights are optimistic of a better society. Through appropriate characterization, themes, settings, dialogue, event /situation and language, they convey their message of positive social change.

\section{CONCLUSION}

This study has investigated the nature, direction, and the degree of the playwrights' commitment over time. The exploration of their plays shed light on the consequences of mismanagement of human and material resources in Nigeria as they draw their themes from the experiences of suffering populace in their country Nigeria. Their plays decry all forms of social injustice, corruption, oppression, dehumanization, poverty, hunger, bad governance, impunity, etcetera. The playwrights through their dramaturgies reflect the socio economic, political, cultural and religious realities in Nigeria in their plays.

The study concludes that Femi Osofisan and Olu Obafemi are great Nigerian playwrights with deep knowledge of the history of Nigeria society which make them draw the themes and settings of their plays from the socio-economic and political realities of the country. Their common rich Yoruba socio-cultural backgrounds, impacted greatly on their creative outputs. They have consistently displayed their ideological commitment to the liberation of the poor in Nigeria and are committed to a positive transformation of the country for the good of all.

The playwrights through their revolutionary creative outputs awaken the consciousness of the oppressed majority to collectively throw off the yoke of oppression and the oppressors. They desire a well-organized and restructured Nigeria where equity, fairness and justice will prevail, where no individual or group will lord it over others but each citizen will be free to maximize his/ her potentials. In essence, the playwrights are consistently committed to positive social change in their society towards bridging the gap between the poor and the rich through conscientisation of the poor to the fact that the source of his poverty is the rich oppressor and exposing the vices perpetrated by the minority rich oppressors.
Through their ideologically committed drama, the playwrights display uncommon commitment to creating a new Nigeria where justice, love, unity and peaceful coexistence of the various ethnic nationalities will be guaranteed.

\section{RECOMMENDATIONS}

This study recommends that the ideology of achieving a better society through collective efforts should be imbibed by promoting the reading and acting of plays by the playwrights in schools and public places for conscientisation of all. Nigerian literary Artists should endeavour to help in setting core values or ethos that will be acceptable to all ethnic groups in their creative outputs and that are relevant for national development, rather than their individual ethnic group values. Ideologically committed literary artists should also get involved in Nigerian politics in order to effect the kind of social change they believe in and propagate in their writings. Government should muster political will to promote national integration, justice, unity, peaceful co-existence, fairness and equity rather than intimidating and harassing literary artists for exposing social vices.

\section{REFERENCES}

[1] Abubakar, A.(2005). Agurumo myth: A recurring metaphor in Olu Obafemi's plays. Anyigba Journal of Arts and Humanities, 4, 24-36.

[2] Abubakar, A. S. (2006). A critical study of revolutionary dialectics and context in Osofisan's drama. (Unpublished doctoral thesis). University of Ilorin, Ilorin.

[3] Abubakar, A. S. (2017). Youths and Nigeria's Economic Revival: An Assessment of the

[4] Premier Production of Obafemi's Love Twirls of Adiitu and Iyunade.(Seminar paper)

[5] Department of English, University of Ilorin.

[6] Achebe, C. (1988). Commitment and the African writer. In T. K. Egonu, (Ed.), Readings in African humanities (pp. 140-156). Owerri: Vivians and Vivians Publishers.

[7] Adelugba, D. \& Obafemi, O. (with additional material by S. Adeyemi). (2004). Anglophone West Africa: Nigeria. In M. Banham (Ed.), A History of Theatre in Africa, Cambridge: Cambridge University Press. (pp. 201-220)

[8] Adeoye, A. A. (2009). The smart game (A Neo-alienation script). Performing Arts Creative Writing SeriesN0. 7.

[9] Amadi, E. (1983). The Question of a Writer's Commitment: Two Points of View Received fromhttp://ro.uow,edu.au./kunapipi/vol 5 /issue (1)/7.

[10] Awodiya, M.P. (1988). Femi Osofisan's theatre. In Y. Ogunbiyi (Ed.), Perspectives on Nigeria Literature, 1700 to the Present Vol. II. 55, (pp. 223-227). Lagos: Guardian Books

[11] Baranger, M. S. (1995). Theatre: A way of Seeing 4th ed). USA: Wadsworth Publishing Company. 
[12] Brecht, B. (1964). A Dialogue with Acting. In J.Willet (Ed.), Brecht on Theatre (pp.26-29).New York: Hilland Wang.

[13] Brockett, O. G. \& Ball, R. J. (2004). The essential of Theatre. $8^{\text {th }}$ Edition. USA: Thomson \& Wadswortth.

[14] Cuddon, J. A. (2013). A dictionary of literary terms. London: Blackwell $5^{\text {th }}$ edition.

[15] Douglas, K. (2007). Illuminations: The Critical Theory Project Brecht's Marxist Aesthetic Retrieved from http://www.gseis.ucla.edu/faculty/kellner/kellner.html

[16] Edde, I. (1991). Understanding Brecht and Soyinka. Lagos: Kraft Books.

[17] Ewen, F. (1969). Bertolt Brecht: His Life, His Art, and His Times. New York: Citadel Press.

[18] Gbilekaa, S. (1997). Radical theatre in Nigeria. Ibadan: Caltop Publications Nigeria Ltd.

[19] Ikerionwu, L.O. (2014). Social transformation in modern drama: A study of selected Nigerian plays. (Unpublished doctoral thesis.). Kogi State University, Anyigba.

[20] Jeyifo, B. (1985). The truthful lie: Essays in the sociology of African drama. London. New Beacon Books.

[21] Obafemi, O. \& Yerima, A. (2004). Ideology and stagecraft in Nigerian theatre. Lagos: Bookplus Nigeria Limited.

[22] Obafemi, O. (2015). The new dawn. Ilorin: Haytee Press and Publishing Co. Nig. Ltd.

[23] Obafemi, O. (2016). Love Twirls of Adiitu and Iyunade. Ilorin: University of Ilorin Press.

[24] Obiechina, E. (1988). The writer and his commitment in contemporary Nigerian society. Okike Nos 27/28).

[25] Odekunle-Awoyale, C. (2000). Orature in Olu Obafemi's plays: Pestle on the Mortar and The New DawnIn D. Oni \& S. E. Ododo (Eds.). Larger than his frame: Critical studies and reflections on Olu Obafemi (pp. 206-214). Lagos: Centre for Black and African Arts and Civilization.

[26] Ogu, J. (1986). Modern African literature: Literary echo of cultural and political reality. In E. Emenyeonu (Ed.), Literature and Society: Selected essays on literature (pp. 112-126).Oguta: Zim Pan African Publishers.

[27] Ojediran, O. (2016). Exposition of a Gendered culture in two selected Nigerian Male Playtexts.

[28] In O.G. Ejue (Ed.), New Frontiers: A Journal in the Humanities, 1, No (1), (pp. 166-179).

[29] Osofisan, F. (1982). Red is the Freedom Road in Morountodun and Other plays. Lagos:

[30] Longman Nigeria Limited.

[31] Osofisan, F. (2002). Altine's wrath. Lagos: Concept Publications Limited.

[32] Osofisan, F. (2017). Personal Interview with the Researcher on $27^{\text {th }}$ July, 2017. 